\title{
Enzymatic and Acid Hydrolysis of Sago Starch for Preparation of Ethanol Production
}

\author{
ROFIQ SUNARYANTO ${ }^{*}$, BERTI HARIASIH HANDAYANI ${ }^{2}$, AND RATU SAFITRI ${ }^{2}$ \\ ${ }^{\prime}$ Center of Biotechnology BPPT, Kawasan PUSPIPTEK Serpong, Tangerang Selatan 15314,Banten, Indonesia; \\ ${ }^{2}$ Deparment of Biology, Faculty of Mathematics and Natural Sciences, Universitas Padjadjaran, Jalan Raya Bandung- \\ Sumedang KM 21 Jatinangor, Sumedang 45363, West Java, Indonesia
}

\begin{abstract}
A series of studies on the hydrolysis of sago starch for ethanol fermentation had been conducted. Hydrolysis of sago starch was carried out using sulfuric acid $2.5 \%$ and amylase(s) enzymes. The concentrations of sago starch used in this experiment were $5,10,15,20$, and $30 \%(\mathrm{w} / \mathrm{v})$. The highest hydrolysate containing reducing sugar was used as substrate for ethanol fermentation by Saccharomyces cerevisiae FNCC 3012. The results indicated that hydrolysis using $2.5 \%$ sulfuric acid for $120 \mathrm{~min}$ at $121{ }^{\circ} \mathrm{C}$ produced $6.6 \%(\mathrm{w} / \mathrm{v})$ reducing sugar and hydrolysis using $\alpha$-amylase and Dextrozyme DX produced more reducing sugar $7 \%(\mathrm{w} / \mathrm{v})$ and $17.1 \%$ $(\mathrm{w} / \mathrm{v})$, respectively. The fermentation of hydrolyzed sago starch by S. cerevisiae FNCC 3012 produced ethanol $7.98 \%(\mathrm{v} / \mathrm{v})$.
\end{abstract}

Key words: enzyme and acid hydrolysis, ethanol fermentation, Saccharomyces cerevisiae, sago starch

Telah dilakukan penelitian hidrolisis pati sagu dan fermentasi hidrolisatnya menjadi etanol. Hidrolisis pati sagu dilakukan dengan menggunakan asam sulfat encer 2,5\% dan enzim amilase. Hidrolisa pati sagu dilakukan pada konsentrasi $5,10,15,20$, and $30 \%(\mathrm{~b} / \mathrm{v})$. Hidrolisat dengan gula pereduksi tertinggi digunakan sebagai substrat untuk fermentasi etanol dengan menggunakan strain Saccharomyces cerevisiae FNCC 3012. Hidrolisis menggunakan asam sulfat $2,5 \%$ pada suhu $121^{\circ} \mathrm{C}$ selama 120 menit menghasilkan gula pereduksi $6,6 \%(\mathrm{~b} / \mathrm{v})$ sedangkan hidrolisis dengan menggunakan $\alpha$-amylase dan Dextrozyme DX menghasilkan konsentrasi gula pereduksi tertinggi berturut-turut sebesar $7 \%(\mathrm{~b} / \mathrm{v})$ dan $17,1 \%(\mathrm{~b} / \mathrm{v})$. Fermentasi hidrolisat pati sagu menggunakan isolat S. cerevisiae FNCC 3012 menghasilkan etanol dengan konsentrasi sebesar 7,98\% (v/v).

Kata kunci: fermentasi etanol, hidrolisa enzim dan asam, pati sagu, Saccharomyces cerevisiae

Starch production from sago palm is common in the Asia Pacific region and South East Asia (Singhal et al. 2008). At the end of $20^{\text {th }}$ century, it was estimated that about 60 million tons of sago starch, derived from sago palms, were produced annually in South-East Asia alone (Wee et al. 2011). The yield of sago starch is higher (25 tons starch/ha/year) than other crops like cassava ( 2 tons) and maize ( 1 ton) (Karim et al. 2008). Due to its abundance, sago may be utilized for the production of fermentable sugars. This can be accomplished economically at large scale with the use of starch-saccharifying enzymes. Adinarayan and Suren (2005) have reported that hydrolysis using starchsaccharifying enzymes have replaced the conventional acidic hydrolysis method. These enzymes account for approximately a $15 \%$ share in the global enzyme market.

Products of starch hydrolysis such as maltodextrin, corn syrup, glucose syrup, and high glucose syrup have a wide application in the food, textile, brewing, ethanol, and pharmaceutical industries (Soto et al.

*Corresponding author; Phone/Fax: +62-21-7560208; Email: rofiqsn@yahoo.com
2012). The sugars from sago starch can be used as feedstocks in fermentation industries, ethanol fermentation and also for the production of highfructose syrup (Suraini 2002). An example of the enzymes that might be involved in the starch hydrolyitic process is glucoamylase (EC 3.2.1.3), which hydrolyzes starch into reducing sugars such as glucose and maltose.

Fermentation-derived ethanol can be produced from sugar, starch or lignocellulosic biomass. Sugar and starch-based feedstocks are currently predominant at the industrial level and, so far, economically favourable (Subashini et al. 2011). Starch-based materials are currently most utilized for the ethanol production in North America and Europe (Kim and Dale 2004). The hydrolysis of starch may be considered as a key step in the processing of starch-based feedstock for the bioethanol production (Drapoch 2008). This step plays a role in effectively converting two major starch polymer components, amylose, a mostly linear $\alpha$-D-(14)-glucan, and branched amylopectin, to fermentable sugars that could subsequently be converted to ethanol by yeasts or bacteria (Woiciechowski et al. 2002). The 
most commonly used distiller's yeast Saccharomyces cerevisiae is unable to hydrolyse starch. Traditional production of ethanol from starch requires a three-stage process; liquefaction of starch by $\alpha$-amylase, saccharification of liquefied starch by enzymes to sugars followed by fermentation using $S$. cerevisiae. Amylolytic enzymes from bacteria and fungi are used for the saccharification of starch and this adds to the overall cost of the bioethanol production process (Yetty et al.2000).

In this study, $2.5 \%$ sulfuric acid, $\alpha$-amylase, and also Dextrozyme DX (contaning glucoamylase and pullulanase) were used to hydrolyze sago starch into reducing sugars, which were then used for ethanol fermentation by S. cerevisiae FNCC 3012. The purpose of this study was to determine the degree of sago starch hydrolysis by acidic and enzymatic methods and to determine the ethanol production profile using the hydrolyzed sago starch.

\section{MATERIAL AND METHODS}

Preparation of Acid-Treated Sago Starch. Sago starch of 5, 10, 15, 20, and $30 \mathrm{~g}$ were dissolved in 200 $\mathrm{mL}$ demineralized water. Sulfuric acid $2.5 \%$ were added to adjust to $\mathrm{pH}$ range $1.0-2.0$. The starch suspension was then refluxed at $121^{\circ} \mathrm{C}$ for $120 \mathrm{~min}$. After cooling, $\mathrm{NaOH}$ was added to the starch to neutralize the $\mathrm{pH}$. The final volume was noted. During incubation, samples were taken every $20 \mathrm{~min}$ (at 0,20 , $40,60,80$, and $120 \mathrm{~min})$. The reducing sugars concentration was measured.

Preparation of Enzyme-Treated Sago Starch. There were two stages in enzymatic sago starch hydrolysis, liquefaction and saccharification. Liquefaction was performed using $1.5 \mu \mathrm{L} \mathrm{g}^{-1}$ (enzyme volume/weight of substrate) $\alpha$-amylase $\left(8222 \mathrm{U} \mathrm{mL}^{-1}\right)$ from Bacillus amyloliquefaciens A7595 (SIGMA) at $85{ }^{\circ} \mathrm{C}$ for $140 \mathrm{~min}$ and agitation $150 \mathrm{rpm}$. During incubation, samples were withdrawn every $20 \mathrm{~min}$ (at $0,20,40,60,80,100,120$, and $140 \mathrm{~min}$ ) and the reducing sugars concentration was measured.

The product of the liquefaction process was then used as a substrate in saccharification. Prior to saccharification, the substrate temperature was cooled down from $85{ }^{\circ} \mathrm{C}$ to $61^{\circ} \mathrm{C}$. Then, the $\mathrm{pH}$ of the substrate was set at about 4.3 using $2 \mathrm{~N} \mathrm{HCl}$ solution. A beaker glass containing the substrate was placed in a shaking-waterbath for $15 \mathrm{~min}$ at $61^{\circ} \mathrm{C}, 150 \mathrm{rpm}$ agitation speed. Then $0.7 \mu \mathrm{L} \mathrm{g}^{-1}$ dextrozyme DX (24 $904 \mathrm{U} \mathrm{mL}^{-1}$ ) (volume of enzyme/weigh of substrate) was added followed by further incubation for $60 \mathrm{~h}$ at the same condition. Dextrozyme DX is the one of a Novozymes product, that is a mixture of glucoamylase (produced by Aspergillus niger) and pullulanase (produced by Bacillus licheniformis). While incubating, samples were withdrawn every $12 \mathrm{~h}$ (at 12, 24, 36, 48, and $60 \mathrm{~h}$ ). The reducing sugars concentration was measured.

Determination of $\alpha$-amylase Activity. Prior to the enzymatic reaction, a aliquot of the soluble starch solution $(1.9 \mathrm{~mL}, 2 \%(\mathrm{w} / \mathrm{v})$ in acetate buffer $\mathrm{pH} 5)$ was heated at $85^{\circ} \mathrm{C}$ for $15 \mathrm{~min}$ in a shaking-waterbath. The enzymatic reaction was initiated by adding $0.1 \mathrm{~mL}$ of the $\alpha$-amylase solution to the pre-heated substrate. The mixture was then incubated for $20 \mathrm{~min}$ at $85{ }^{\circ} \mathrm{C}$ and $150 \mathrm{rpm}$. The reaction was stopped by heating in boiling water for $5 \mathrm{~min}$, followed by cooling on the room temperature. Afterwards, the reduction sugar was analyzed using method specified by Nelson and Somogyi (1952). One unit of $\alpha$-amylase activity was defined as the amount of $\alpha$-amylase required to liberate $1 \mu \mathrm{moL}$ of reduction sugar (maltose) from starch per minute at $85^{\circ} \mathrm{C}, \mathrm{pH} 5$.

Determination of Dextrozyme DX Activity. Prior to enzymatic reaction, a soluble starch solution $(1.9 \mathrm{~mL} \mathrm{2 \%}(\mathrm{b} / \mathrm{v}))$ in acetate buffer $\mathrm{pH} 5$ was heated at $61^{\circ} \mathrm{C}$ for $15 \mathrm{~min}$ in a shaking-waterbath. The enzymatic reaction was initiated by adding $0.1 \mathrm{~mL}$ of the Dextrozyme DX solution to the pre-heated substrate. The mixture was then incubated for $20 \mathrm{~min}$ at $61^{\circ} \mathrm{C}$, $150 \mathrm{rpm}$. The reaction was stopped by heating in boiling water for $5 \mathrm{~min}$, followed by cooling at room temperature. Afterwards, the reducing sugar was analyzed using method specified by Nelson and Somogyi (1952). One unit of Dextrozyme DX activity was defined as the amount of enzyme required to liberate $1 \mu \mathrm{moL}$ of reduction sugar (glucose) from starch per minute at $61^{\circ} \mathrm{C}, \mathrm{pH} 5$.

Ethanol Fermentation. Hydrolyzed sago starch (saccharified) containing the highest concentration of reducing sugar is used as fermentation substrate. Hydrolyzed sugar was filtered using standard filter paper. Then, the concentration of the reducing sugars in the substrate was set between 14-18\% (w/v) (Putri and Sukandar 2008). Nutritions, in the form of $4 \%(\mathrm{w} / \mathrm{v})$ ammonium sulfate $\left[\left(\mathrm{NH}_{4}\right)_{2} \mathrm{SO}_{4}\right]$ and $1 \%(\mathrm{w} / \mathrm{v})$ peptone, were added. Afterwards, the $\mathrm{pH}$ was adjusted to 4.5-5.0 using $0.1 \mathrm{~N} \mathrm{HCl}$. Fermentation substrates were sterilized in an autoclave for $15 \mathrm{~min}$ at $121^{\circ} \mathrm{C}, 1 \mathrm{~atm}$. Five $\mathrm{mL}$ culture of $S$. cerevisiae FNCC 3012 containing $2 \times 10^{5}$ cells was used to inoculate $50 \mathrm{~mL}$ 
fermentation substrate $(9 \%(\mathrm{v} / \mathrm{v})$ inoculum size $)$. Then, the culture was incubated while shaking for $48 \mathrm{~h}$ at 28 ${ }^{\circ} \mathrm{C}, 150 \mathrm{rpm}$. Samples were obtained every $12 \mathrm{~h}$ (at 0 , $12,24,36$, and $48 \mathrm{~h}$ ).

Analysis of Ethanol Concentration. Ten $\mathrm{mL}$ of fermentation broth was centrifuged at $5000 \mathrm{rpm}$ for 30 min and the supernatant was used to estimate the ethanol concentration. Ethanol was analyzed by gas chromatography (GC-14A SHIMADZU) equipped with Carbowax column at $150{ }^{\circ} \mathrm{C}$, flame ion detector (FID) $200^{\circ} \mathrm{C}$ and injector $200{ }^{\circ} \mathrm{C}$. Nitrogen was used as carrier gas at flow rate $30 \mathrm{~cm}^{3} \mathrm{~min}^{-1}$ and the combustion gas was a mixture of hydrogen and air.

Analysis of Reducing Sugar. The reducing sugar concentration in the samples was estimated using method specified by Nelson and Somogyi (1952). Twenty five $\mathrm{mL}$ of sample was withdrawn at regular intervals cooled to room temperature and then filtered through muslin cloth. The filtrate was centrifuged at $3000 \mathrm{rpm}$ for $15 \mathrm{~min}$. The clear supernatant of the hydrolysate was taken for determination of reducing sugar. Sugar was extracted with $80 \%$ ethanol twice. The supernatant was evaporated by keeping it in water bath at $80^{\circ} \mathrm{C}$ and the residue was dissolved by adding $10 \mathrm{~mL}$ water. Aliquots $(0.1 \mathrm{~mL})$ of each sample was pipetted into test tubes and simultaneously $0.2,0.4,0.6$, 0.8 , and $1 \mathrm{~mL}$ of working standard were pipetted out into test tubes. Volumes of samples and standards were made up to $2 \mathrm{~mL}$ with distilled water. One $\mathrm{mL}$ of alkaline copper tartarate reagent was added to each tube containing $1 \mathrm{~mL}$ of distilled water blank. The tubes were placed in boiling water for $10 \mathrm{~min}$ and after cooling $1 \mathrm{~mL}$ of arsenomolybdate reagent was added. Finally, the volume was made up with distilled water to $10 \mathrm{~mL}$ and left for $10 \mathrm{~min}$. Absorbance was read at 620 $\mathrm{nm}$ using spectrophotometer and the values were plotted in a graph against concentration. Reducing sugars present in the sample were calculated and expressed in terms of percentage.

\section{RESULTS}

Effect of Different Sago Starch Concentrations on the Saccharification Using Sulphuric Acid at Different Time Intervals. Effect of different concentrations of sago starch on saccharification by $2.5 \% \mathrm{H}_{2} \mathrm{SO}_{4}$ was tested at different time points with 20 min intervals. The maximum amount of reducing sugar observed at $2.5 \% \mathrm{H}_{2} \mathrm{SO}_{4}$ showed that both $20 \%(\mathrm{w} / \mathrm{v})$ and $30 \%(\mathrm{w} / \mathrm{v})$ sago starch produced the highest concentrarion of $6.6 \%(\mathrm{w} / \mathrm{v})$ reducing sugar (Fig 1A).
At sago starch concentration range 5\%-20\% (w/v) there was proportional correlation between starch concentration and reducing sugar, where higher starch concentration produced higher concentration of reducing sugar (Fig 1A). This is reasonable since higher concentration of starch meant there were more contacts between molecules of starch and acid, so more reducing sugar is produced. But this did not occur at $30 \%$ (w/v) sago starch concentration. Substrate viscosity might also affect the hydrolysis process. Sago starch of $30 \%(\mathrm{w} / \mathrm{v})$ seemed thicker and stickier than sago starch $20 \%, 15 \%, 10 \%$, and $5 \%(\mathrm{w} / \mathrm{v})$. However, the amount of reducing sugar produced from this acid hydrolysis was low.

Effect of Different Sago Starch Concentrations on Liquefaction Using $\alpha$-Amylase at Different Time Intervals. Prior to being used in the experiments, the volumetric activities of the $\alpha$-amylase and Dextrozyme DX were determined using soluble starch as substrate. The volumetric activies of the $\alpha$-amylase and Dextrozyme DX were $8222 \mathrm{U} \mathrm{mL}^{-1}$ and $24904 \mathrm{U} \mathrm{mL}^{-1}$, respectively.

Effect of different sago starch concentrations on the liquefaction using $\alpha$-amylase was tested at different time points with 20 min time intervals. The maximum amount of reducing sugar $(7 \%(\mathrm{w} / \mathrm{v}))$ was observed when $20 \%(\mathrm{w} / \mathrm{v})$ sago starch and 140 min production time was used (Fig 1B). This result was better than when other sago starch concentrions $(30 \%, 15 \%, 10 \%$, and $5 \%(\mathrm{w} / \mathrm{v}))$ were used, attaining $6,5.2,3.8$, and 1.3 $\%(\mathrm{w} / \mathrm{v})$, respectively. Higher substrate concentration would normally produce more product. However, in this case, 30\% (w/v) sago starch produced less reducing sugar in comparison to $20 \%(\mathrm{w} / \mathrm{v})$ sago starch. This might be related to the viscosity of the substrate solution. High viscosity will affect the substrate-enzyme interaction, thus reducing the amount of reaction product.

Effect of Sago Starch Different Concentrations on Saccharification Using Dextrozyme DX at Different Time Intervals. Effect of different sago starch concentrations on saccharification using dextrozyme DX was tested at different time points with $10 \mathrm{~h}$ intervals. The maximum amount of reducing sugar was observed at $20 \%$ sago starch. The result was higher than when $30 \%, 15 \%, 10 \%$, and $5 \%(\mathrm{w} / \mathrm{v})$ sago starch were used (Fig 1C).

Apart from having the best effect on the liquefaction process, $20 \%(\mathrm{w} / \mathrm{v})$ sago starch also produced the highest concentration of reducing sugar $(17.1 \%(\mathrm{w} / \mathrm{v}))$. This was better than $30 \%, 15 \%, 10 \%$, and $5 \%(\mathrm{w} / \mathrm{v})$ 

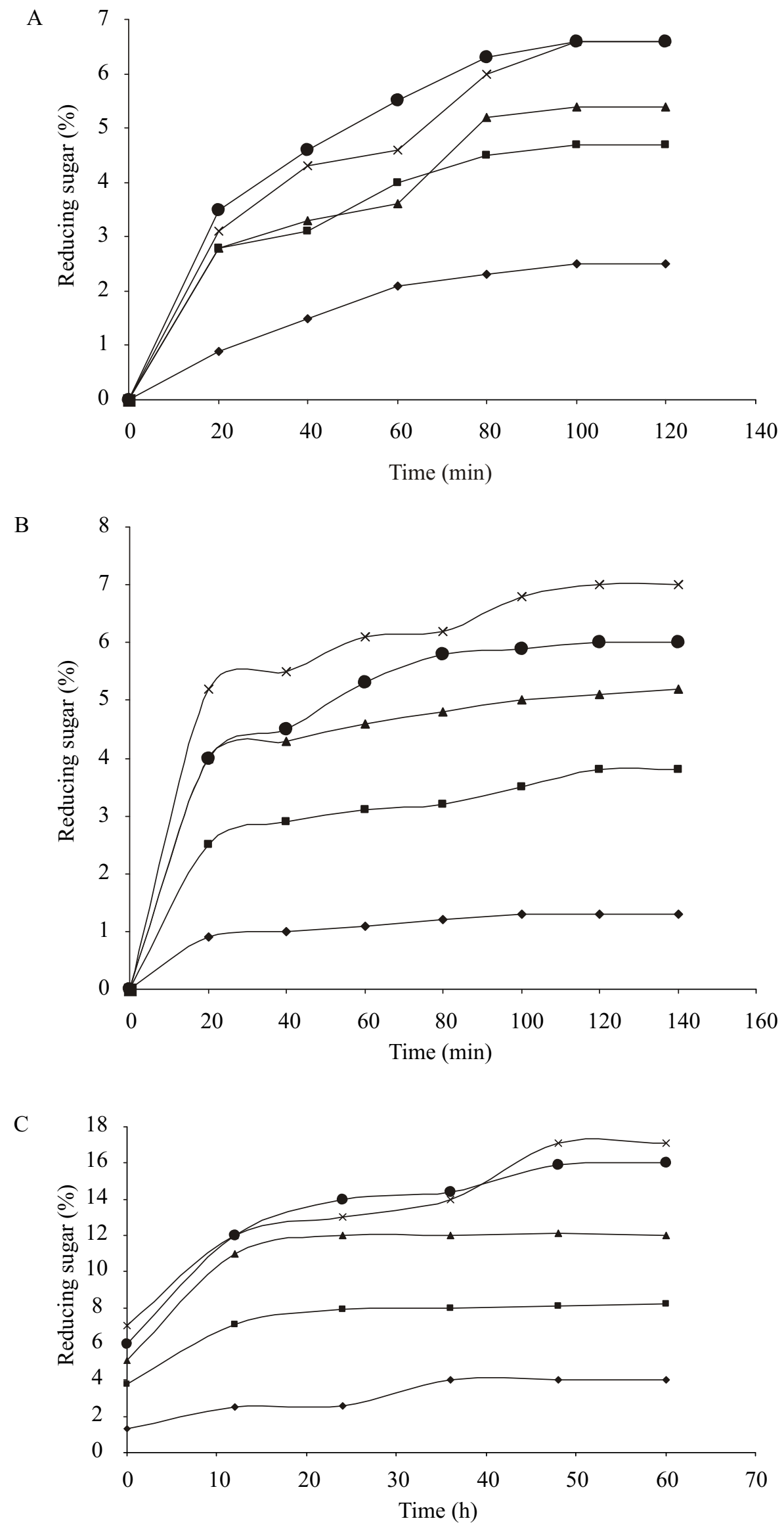

Fig 1 Profile of sago starch hydrolyses by $2.5 \% \mathrm{H}_{2} \mathrm{SO}_{4}(\mathrm{~A})$, liquefaction using $\alpha$-amylase (enzyme activity $8222 \mathrm{U} \mathrm{mL}^{-1}$ ) (B), and saccharification using dextrozyme DX (enzyme activity $\left.24904 \mathrm{U} \mathrm{mL}^{-1}\right)(\mathrm{C})$, at different concentrations $(5,10,15,20$,

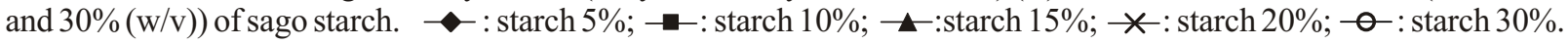


sago starch, which produced only $16,12,8.2$, and $4 \%$ (w/v) reducing sugar, respectively (Fig 1C). Figure 1C showed that the saccharification using $20 \%(\mathrm{w} / \mathrm{v})$ sago starch produced more reducing sugar than $30 \%(\mathrm{w} / \mathrm{v})$ sago starch. Similarly to liquefaction process, the high viscosity of sago starch reduced the possibility of substrate-enzyme interaction, thus the conversion yield was lower. In the subsequent study, saccharification using $20 \%$ (w/v) sago starch were used.

The ethanol fermentation was conducted by $S$. cerevisiae FNCC 3012 for $48 \mathrm{~h}$ at $28^{\circ} \mathrm{C}, 150 \mathrm{rpm}$. The highest sugar consumption rate occurred in the logarithmic phase (Fig 2). At the same time, cell growth was also high and $\mathrm{pH}$ decreased. Ethanol production occurred simultaneously with cell growth. Stationary phase was achieved after $36 \mathrm{~h}$, where there was no more increase of cell number and the rate of ethanol production was constant. At the same time, sugar consumption declined. Declining of sugar concentration had slowed down the cell growth and many cells started to lyse. Maximum ethanol concentration $(7.98 \%(\mathrm{w} / \mathrm{v}))$ was attained after $36 \mathrm{~h}$.

\section{DISCUSSION}

The maximum amount of reducing sugar obtained by saccharification using $2.5 \% \mathrm{H}_{2} \mathrm{SO}_{4}$ was $6.6 \%$ (w/v). Acid breaks down starch molecules at random and generates more reducing sugars. Theoretically, hydrolysis of starch into glucose produces $60 \%$ glucose (Woiciechowski et al. 2002). However, in this study the highest concentration of reducing sugar obtained was $6.6 \%(\mathrm{w} / \mathrm{v})$. The major products of glucose decomposition that were identified as 50 hydroxymethylfurfural (HMF), 1,6-anhydroglucose, levulinic acid, and formic acid (Xiang et al.2004).

Effect of different sago starch concentrations on liquefaction by $\alpha$-amylases showed that $20 \%(\mathrm{w} / \mathrm{v})$ sago starch produced the highest concentration of reducing sugar $(7 \%(\mathrm{w} / \mathrm{v}))$, followed by $30 \%(\mathrm{w} / \mathrm{v})$ sago starch that produced $6(\mathrm{w} / \mathrm{v}) \%$ reducing sugar. $\alpha$ amylases (1,4-D-glucan glucanohydrolases) are endohydrolases which cleave 1,4- $\alpha$-D-glucosidic bonds and can bypass but cannot hydrolyse 1,6- $\alpha-\mathrm{D}$ glucosidic branchpoints. Commercial enzymes used for the industrial hydrolysis of starch are produced by B. amyloliquefaciens. The principal requirement for liquefaction is to reduce the viscosity of the gelatinized starch to ease subsequent processing. At liquefaction process, "maltodextrin" is obtained which contains mainly different oligosaccharides and dextrins. Maltodextrins are only slightly sweet and they usually

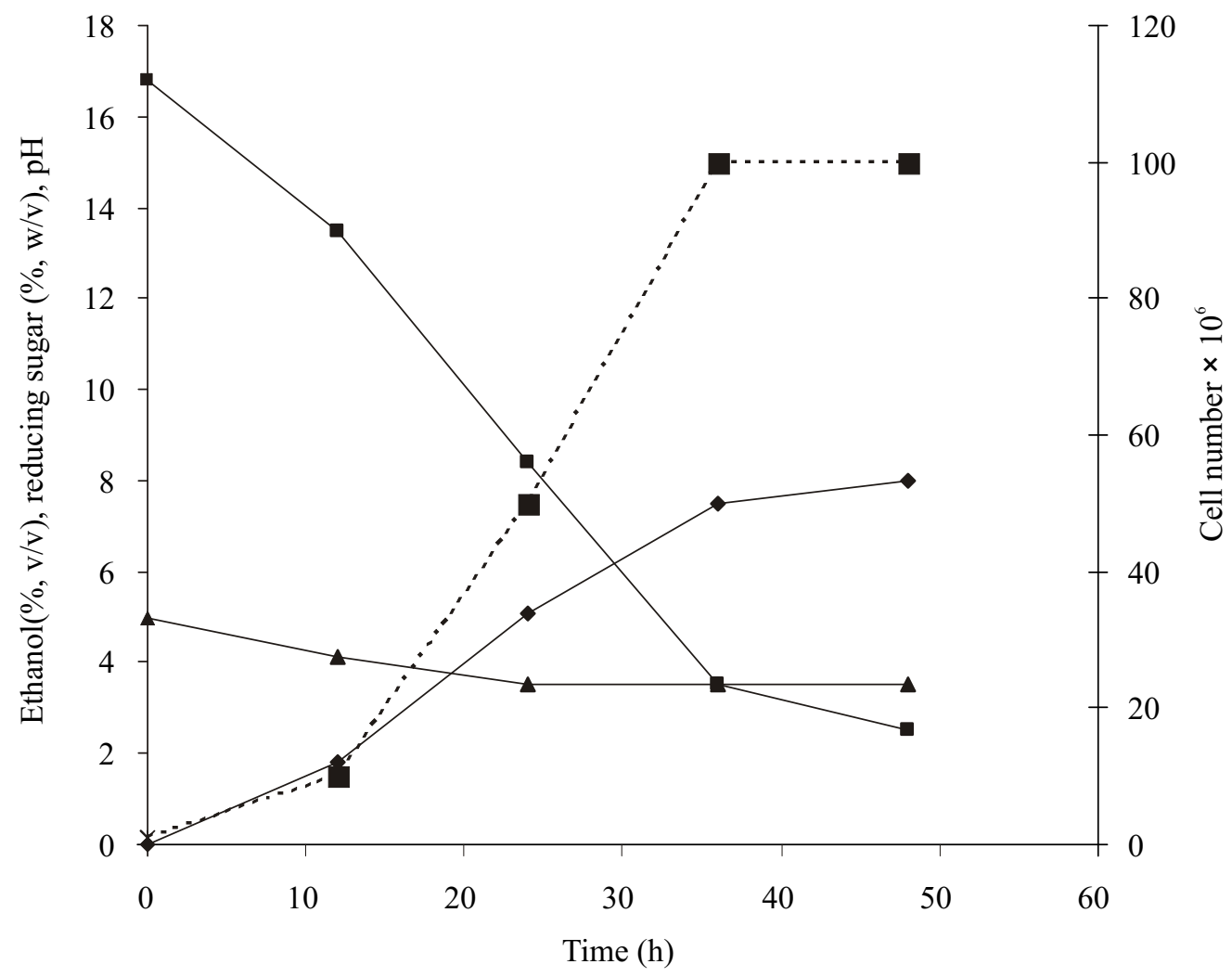

Fig 2 Time course of ethanol fermentation using hydrolyzed sago starch by Saccharomyces cerevisiae FNCC 3012. $\multimap$ :ethanol $\%(\mathrm{v} / \mathrm{v}) ; \rightarrow-$ Reduction sugar $(\%)(\mathrm{b} / \mathrm{v}) ; \multimap: \mathrm{pH}$; and 
undergo further conversion. Various manufacturers use different approaches to starch liquefaction using $\alpha$ amylases but the principles are the same.

On the saccharification step using dextrozyme DX, $20 \%(\mathrm{w} / \mathrm{v})$ sago starch produced the highest reducing sugar concentration $(17.1 \%(\mathrm{w} / \mathrm{v}))$. Dextrozyme DX containing amyloglucosidase-pullulanase enzyme. A glucoamylase is used to further break down the Maltodextrins. The glucoamylase can hydrolyze starch completely to glucose along with, a little maltose and isomaltose. A pullulanase is a de-branching enzyme that can also be used to aid saccharification. Reducing sugars of various sizes are formed when starch is converted to fermentable sugars. Normally, higher reducing sugar levels indicates higher proportion of smaller sugar molecules in the mixture, which are easier to ferment.

In the ethanol fermentation, the reducing sugars concentration in the substrate was set between 14-18\% $(w / v)$. This concentration was selected according to previous results published by others (Putri and Sukandar (2008)). Putri and Sukandar (2008) had produced $8.6 \%(\mathrm{v} / \mathrm{v})$ ethanol from $S$. cerevisiae $\mathrm{FNCC}$ 3012 fermentation using $14 \%(\mathrm{w} / \mathrm{v})$ hydrolyzed Ganyong starch as carbon source. Our study using the same isolate but instead, hydrolyzed sago starch, as carbon source produced $7.98 \%(\mathrm{w} / \mathrm{v})$ ethanol.

The ethanol formation occurred along with lag and exponential phase and showed maximum concentration after the growth reached stationary phase. This indicates that ethanol production was associated with cell growth. At the exponential phase, sugar consumption was highest and $\mathrm{pH}$ decreased sharply. Decomposition of sugar releases proton and causing $\mathrm{pH}$ to decrease sharply. The highest ethanol concentration $(7.98 \%(\mathrm{v} / \mathrm{v}))$ was obtained after $48 \mathrm{~h}$ cultivation. However, after $36 \mathrm{~h}$ the productivity of ethanol had already slowed down and the cell number no longer increased.

The low productivity of ethanol can be affected by several factors; first of all, the ability of isolates to produce ethanol (type of isolate), especially for wild type strain such as $S$. cerevisiae FNCC 3012, which had never been tested as industrial strain, secondly, the presence of product (ethanol) inhibition. In the previous study, S. cerevisiae FNCC 3012 had been used to produce ethanol $(8.98 \%(\mathrm{v} / \mathrm{v}))$ using nipah (Nypa fruticans) sap as carbon source (Trisasiwi et al. 2011). According Amenaghawon et al. (2012) the inhibitive effect of ethanol can affect the specific growth rate, product yield and specific ethanol production rate during batch ethanol fermentation. Solid State Fermentation (SSF) method enables attainment of higher ethanol yields by removing endproduct inhibition like ethanol inhibition (Lin and Tanaka 2006). However, in this study we did not carry out the solid state fermentation for ethanol production.

\section{REFERENCES}

Adinarayaan K and Suren S. 2005. Response surface optimization of enzymatic hydrolysis of maize starch for higher glucose production. Biochem Eng J. 6(3):179190. doi:10.1208/pt060348.

Amenaghawon NA, Okieimen CO, Ogbeide S. 2012. Kinetic modelling of ethanol inhibition during alcohol fermentation of corn stover using Saccharomyces cerevisiae. Inter J Eng Res Appl. 2(4):798-803.

Drapoch. 2008. Biofuel feed stock. New York: McGraw-Hill Companies Inc. p 69-78.

Karim AA, Tie AP, Manan DMA, Zaidul ISM. 2008. Starch from the Sago (Metroxylon sagu) palm tree; properties, prospects, and challenges as a new industrial source for food and other uses. Rev Food Sci Food Safety. 7(3): 215-228. doi: 10.1111/j.1541-4337.2008.00042.x.

Kim S, Dale BE. 2004. Global potential bioethanol production from wasted crops and crop residues. Biomass Bioenerg. 26(4):361-375.

Lin Y, Tanaka S. 2006. Ethanol fermentation from biomass resources: current state and prospects. Appl Microbiol Biotechnol. 69(6): 627-642. doi:10.1007/s00 253-005-0229-X.

Nelson N, Somogyi M. 1952. A photometric adaptation for the Somogyi method for the determination of glucose. J Biol Chem 153: 375-380.

Putri LSE, Sukandar D. 2008. Starch conversion of Ganyong (Canna edulis Ker.) to bioethanol using acid hydrolysis and fermentation. Biodiversitas 9(2):112-116.

Ren Q, Huang Y, Ma H, Wang F, Gao J, Xu J. 2013. Convertion of glucose to 5-Hydroxymethylfurfural catalyzed by metal halide in N,N-Dimethylacetamide. Bioresources 8(2):1563-1572.

Singhal R S, Kennedy J F, Gopalakrishnan SM, Kaczmarek A, Knill CJ, Akmar PF. 2008. Industrial production, processing, and utilization of sago palm-derived products. Carbohyd Polym. 72(1):1-20. doi:10.1016/j. carbpol.2007.07.043.

Somda MK, Savadogo A, Ouattara CAT, Ouattara AS, Traore AS. 2011. Improvement of bioethanol production using amylasic properties from Bacillus licheniformis and yeasts strains fermentation for biomass valorization. Asian J Biotechnol. 3(3):254261.

Soto JLM, Garcia LM, Gonzalez JV, Nicanor AB, Cruz LG. 2012. Influence of starch source in the required hydrolysis time for the production of maltodextrins with different dextrose equivalent. Afr J Biotechnol. 
11(69):13428-13435.doi: 10.5897/AJB12.2257.

Subashini D, Ejilane J, Radha A, Jayasri MA, Suthindhiran K. 2011. Ethanol production from Sago waste using Saccharomyces cerevisiae Vits-M1. Curr Res J Biol Sci. 3(1):42-51.

Suraini AA. 2002. Review: Sago starch and its utilization. J Biosci Bioeng. 94: 526-529.

Trisasiwi W, Asnani A, Setyawati R. 2011. Optimization of bacterial doses and incubation time on bio-ethanol fermentation of Nipah (Nypa fruticans) for biofuel energy. J Life Sci. 5(12):1022-1029.

Wee LL, Annuar MSM, Ibrahim S. 2011. Energetics of glucoamylase-catalyzed hydrolysis of commercial Sago starch. Asia Pac J Mol Biol Biotechnol. 19(4):117-120.
Woiciechowski AL, Nitsche S, Pandey A, Soccol CR. 2002. Acid and enzymatic hydrolysis to recover reducing sugars from cassava bagasse: an economic study. Braz Arch Biol Technol. 45(3):393-400. doi:10.1590/S151689132002000300018 .

Xiang Q, Yong Y, Lee, Torget RB. 2004. Kinetic of glucose decomposition during dilute acid hydrolysis of lignocellulosic biomass. App Biochem Biotechnol. 115(1-3):1127-1138. doi:10.1385/ABAB:115:1-3:1127.

Yetti M, Saari N, Hassan Z, Radu S. 2000. Improvement in raw sago starch degrading enzyme production from Acremonium sp. endophytic fungus using carbon and nitrogen sources. Enzyme Microbiol Tech. 27(7):511515. doi:10.1016/S0141-0229(00)00243-X. 